Témoigner Témoigner. Entre histoire et mémoire

Getuigen Revue pluridisciplinaire de la Fondation Auschwitz

$125 \mid 2017$

Histoire et mémoire de la persécution des

homosexuel-le's par les nazis

\title{
Dessins assassins of een geschiedenis van het antisemitisme in cartoons
}

Dessins assassins ou la corrosion antisémite (Heinous cartoons)

\section{Frédéric Crahay}

Traducteur : Gorik de Henau

\section{(2) OpenEdition}

Journals

\section{Édition électronique}

URL : https://journals.openedition.org/temoigner/6110

DOI : 10.4000/temoigner.6110

ISSN : 2506-6390

Cet article est une traduction de :

Dessins assassins ou la corrosion antisémite (Heinous cartoons) - URL : https://

journals.openedition.org/temoigner/6109 [fr]

Éditeur :

Éditions du Centre d'études et de documentation Mémoire d'Auschwitz, Éditions Kimé

Édition imprimée

Date de publication : 1 octobre 2017

Pagination : 23-24

ISBN : 978-2-930953-01-4

ISSN : 2031-4183

Référence électronique

Frédéric Crahay, «Dessins assassins of een geschiedenis van het antisemitisme in cartoons»,

Témoigner. Entre histoire et mémoire [Online], 125 | 2017, Online op 24 décembre 2021, geraadpleegd op 04 février 2022. URL: http://journals.openedition.org/temoigner/6110 ; DOI: https://doi.org/10.4000/ temoigner.6110 


\section{DESSINS ASSASSINS OF EEN GESCHIEDENIS VAN HET ANTISEMITISME IN CARTOONS}

TENTOONSTELLING Sinds 22 maart 2017 loopt in het Mémorial de Caen (Frankrijk) een omvangrijke tentoonstelling over het netelige en oeroude probleem van het antisemitisme. Ze bestaat uit 170 stukken en documenten afkomstig uit de privécollectie van Arthur Langerman, een Antwerpse diamantair die in België de Shoah overleefde.

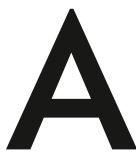

rthur Langerman werd op 21 augustus 1942 geboren in Antwerpen. Zijn familie, die daar tijdens de oorlog ondergedoken zat, werd op 28 maart 1944 door de Gestapo gearresteerd. Zysla Blajwas en Solomon Langerman, zijn ouders, werden naar de Dossinkazerne in Mechelen gestuurd en Arthurwerd ondergebracht in dekinderopvang in de Baron de Castrostraat in Etterbeek. Dat kindertehuis hing af van de Vereeniging van Joden in België (VJB) en stond onder de controle van de Sipo-SD. Op 19 mei 1944 werden zijn ouders met het 25ste transport gedeporteerd naar Auschwitz-Birkenau. Zijn vader overleefde het niet. Zijn moeder werd in augustus 1944 van Auschwitz naar Ravensbrück overgebracht, een concentratiekamp voor vrouwen op een honderdtal kilometer ten noorden van Berlijn. Na repatriëring naar België werd ze herenigd met haar zoontje. Getraumatiseerd als ze was, sprak ze nooit over haar ervaring. Door het proces tegen Adolf Eichmann in 1961 werd Arthur Langerman zich pas echt bewust van het drama dat zijn familie had getroffen. Hij begon een verzameling aan te leggen van antisemitische voorwerpen en documenten: ansichtkaarten, affiches, cartoons enzovoort. Zijn collectie, met ongeveer 7500 originele stukken van de achttiende tot de twintigste eeuw, is momenteel de grootste antisemitische privéverzameling ter wereld.
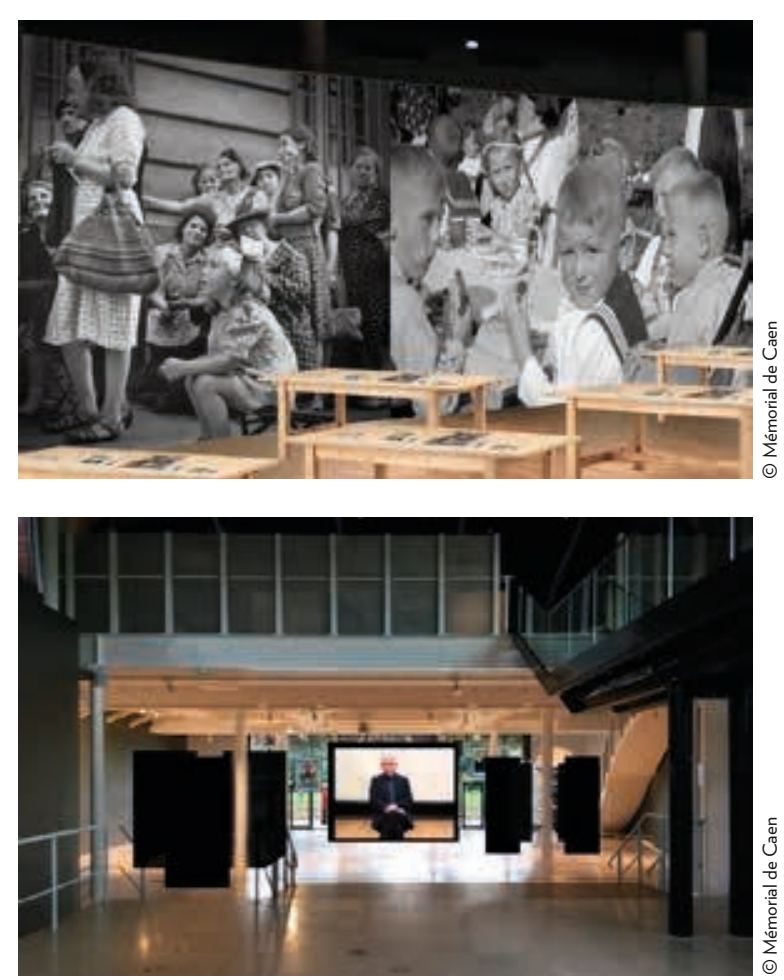

Op basis van deze rijke collectie werd de tentoonstelling Dessins assassins in het Mémorial de Caen samengesteld. De bezoeker wordt meteen verwelkomd met een video-opname van Arthur Langerman, die uitleg geeft over hoe zijn collectie tot stand kwam, de redenen voor zijn engagement en het streven om er een didactische en pedagogische tentoonstelling van te maken. Het traject loopt over twee verdiepingen en omvat antisemitische documenten van het pamflet La France juive van Édouard Drumont (in 1886 verschenen bij Flammarion) tot en met het einde van de Tweede Wereldoorlog in 1945. Elk document wordt in zijn context geplaatst, wat niet onbelangrijk is, want een niet-ingewijd publiek zou de aangeprezen boodschappen verkeerd kunnen interpreteren. De tekeningen, vaak karikaturen, hebben niets aan kracht •.• 
•. ingeboet en zijn vaak bij het grote publiek bekend door het gebruik dat er later van werd gemaakt. De antiJoodse clichés doen zich vaak voor als humoristisch, maar zijn meestal louter sarcastisch, wat in de tentoonstelling mooi tot uiting komt (lees ook: Dessins assassins au Mémorial de Caen, zondagbijlage bij de krant Ouest France, april 2017).

In verband met het probleem dat er haatdragende voorwerpen worden tentoongesteld zegt Stéphane Grimaldi, directeur van het Mémorial de Caen en medebedenker van de tentoonstelling, het volgende: 'Je kunt het niet over antisemitisme hebben zonder het te laten zien, zoals je het ook niet over de Shoah kunt hebben zonder de doden te laten zien.' (bijlage Ouest France, p. 2) Bij het grote publiek vrij bekende gebeurtenissen, bijvoorbeeld de zaak-Dreyfus, worden toegelicht, evenals de sociale en politieke rol die deze roemloze episode tussen 1894 en 1906 speelde in de geschiedenis van de Derde Franse Republiek. De duistere periode wordt op onheilspellende wijze geïllustreerd door de Dreyfuskarikaturen in de reeks La maison des horreurs. Andere documenten genieten minder bekendheid, maar zijn vaak juist suggestiever in hun rabiaat antisemitisme, bijvoorbeeld nummers van Stürmer, het naziweekblad dat van 1927 tot 1945 in Duitsland verscheen. Het getuigde van dagelijkse praktijken waardoor het antisemitisme tijdens het interbellum voor een deel van de Duitse bevolking 'aanvaardbaarder' werd gemaakt.

Het bedenken en organiseren van de tentoonstelling ging niet van een leien dakje. Instellingen als het Joods Museum in Brussel of het Mémorial de la Shoah in Parijs gingen liever niet in op het het aanbod om de collectie van Arthur Langerman te laten zien; ze zeiden niet te willen provoceren ${ }^{1}$, waaruit blijkt dat het onderwerp gevoelig ligt en brandend actueel blijft. In de tentoonstelling wordt trouwens gewezen op het verkeerde gebruik dat we tegenwoordig soms van afbeeldingen maken. In de actuele samenleving, met een overdaad aan beelden, vraagt Dessins assassins de bezoekers eerst na te denken en dan pas tot conclusies of daden over te gaan. Propaganda blijft niet beperkt tot het verleden en de bezoeker die de tijd neemt om de tentoongestelde documenten van nabij te bekijken beseft dit maar al te goed.

(1) François-Guillaume Lorrain, artikel verschenen in Le Point op 23 maart 2017, https://www.pressreader.com/france/ le-point/20170323/283613874984791
Een van de evidente sterke punten van de tentoonstelling (en van de hele Langermancollectie) is dat ze documenten omvat in bijna alle Europese talen. Door de affiches in het Nederlands en Frans bijvoorbeeld wordt het onderwerp meteen bevattelijk voor het potentiële Belgische publiek (scholen of andere). Dit gaat op voor alle Europese landen waar antisemitisme aan de orde was, of nog altijd is. Een van de educatieve doelen van de tentoonstelling is trouwens de aandacht te richten op Europese vormen van nationalisme vroeger en nu. ${ }^{2}$ Een andere expliciete doelstelling is bij de doorsnee bezoeker een kritische geest aan te kweken en te tonen dat de verzamelde tekeningen en schetsen niets met humor van doen hebben. De tentoonstelling kan dan ook rekenen op de steun van de DILCRAH/ Délégation interministérielle à la lutte contre le racisme, l'antisémitisme et la haine anti-LGBT (Franse interministeriële delegatie voor de bestrijding van racisme, antisemitisme en homohaat). ${ }^{3}$ De tentoonstelling maak indruk, zeker in de context van het hedendaagse antisemitisme dat in Frankrijk weer in beeld kwam met de aanslag tegen de supermarkt Hyper Cacher op 9 januari 2015 - een daad waarbij duidelijk de Joodse gemeenschap in Frankrijk werd geviseerd. In België was er de aanslag op het Joods Museum in Brussel een jaar eerder, namelijk op 24 mei 2014.

Wat zijn dan de zwakke punten van deze uitstekende tentoonstelling? Ze zou completer zijn met wat meer uitleg over het verschil tussen antisemitisme (haat tegenover Joden voor wat ze zijn) en anti-judaisme (haat tegenover Joden voor wat ze niet zijn: niet Grieks, Romeins, christelijk enzovoort). Natuurlijk gaat het anti-judaïsme vooraf aan het antisemitisme, dat grotendeels tijdens de negentiende eeuw ontstond; documenten waarmee het anti-judaïsme kan worden geïllustreerd zijn dus niet zo makkelijk te vinden. I

\section{Frédéric Crahay (Auschwitz in Gedachtenis vzw)}

Vertaling uit het Frans: Gorik de Henau

\section{Meer weten \\ De tentoonstelling loopt tot en met 15 december 2017 in het Mémorial de Caen en begint vanaf 2018 aan een rondreis. Volgens plan zal ze in de loop van 2019 te zien zijn in de Dossinkazerne in Mechelen.}

(2) Http://www.telerama.fr/scenes/le-stupefiant-cheminement-de-lahaine-antisemite-en-cent-dessins,159234.php

(3) Http://www.memorial-caen.fr/les-evenements/expositions-temporaires/ 1886-1945-dessins-assassins-ou-la-corrosion-antisemite-en-europe 